\title{
SOME SKETCHES ON SOCIAL NETWORKING WEBSITES
}

\author{
Vincentas Lamanauskas \\ University of Šiauliai, Lithuania \\ E-mail: v.lamanauskas@ef.su.It
}

It is obvious, that usage of social networking websites is constantly growing. In Lithuania, a rapid growth of usage has been observed in recent years, taking into account local (national) social networking websites as well. Facebook.com is one among 10 mostly visited networks in Lithuania. Lithuanian consumers are not an exception - not a small part of them also use several social networking websites. Both in the world and in Lithuania, business takes an active interest in social networking websites. An evident tendency is the expansion of SNW possibilities in business environment. If earlier it was thought that usage of SNW is a waste of time, in the latter years business finds more and more reasons why social networking websites ought to be used. This is marketing, service and product advertisement, new client search, cooperation development and so on. The other thing - the amount and the flow of information will certainly not decrease and therefore information usage and management in general, will remain urgent (Lamanauskas, 2012a).

Social networking websites spread is encouraged firstly by the variety of information communication technologies, constantly changing functions and possibilities. It is obvious, that technology and consumer interaction is bilateral - technologies encourage consumers to try new functions and possibilities, the latter in their own right raise new requirements to technology creators. It is obvious, that together with technological problems arise social internet problems as well. Social networking websites (SNW) are closely related with economical, psychological, educational, valeological and other aspects. There is a lack of research based on socio-educational social networking website aspects. It is important to know not only how much time the consumers spend surfing the net, but how much time is allotted for communicating in social networking websites, which of them are the most popular and why, how the respondents evaluate social networking website functions, what in general they know about them, what advantages, disadvantages and threats they discern. Finally, it is important to find out whether the use of social networking websites makes information - communication abilities better in any way.

The other tendency is also rather distinct. Social networking websites "move" into educational space as well. There are many potential problems with social networking websites in general and in the education area in particular. The problem of motivation to learn and improve remains urgent. Despite education science achievements, motivation encouragement problem remains one of the most serious ones. However, watching children and teenagers' activities using ICT, especially social networking websites, a very high motivation, a need to use SNW are fixated. Thus, it is important to use up that motivation in educational sense, in other words, to use up social networking websites' abilities in educational sense.

In a recent study, Lamanauskas et al. (2012b) presented the results of a survey to ascertain how Lithuanian university students use social networking websites, how they value them, what opinion they have about various social networking websites, and what they know about them (Lamanauskas, Šlekienè, Ragulienė, 2012b). After the additional analysis it became obvious that university students highly value Social networking websites. SNW can be useful for communication and leisure time, also social and information getting needs. SNW is a good way for finding friends, communicating with them. It is obvious that SNW can be effectively used 
Vincentas LAMANAUSKAS. Some Sketches on Social Networking Websites

PROBLEMS

OF EDUCATION

IN THE $21^{\text {st }}$ CENTURY Volume 54, 2013

for acquiring knowledge and getting the newest information from the whole world. Despite the existence of some minor differences between the different study programme students, SNW educational opportunities are quite broad (Lamanauskas, Šlekienè, Balog, Pribeanu, 2013).

Thus, can social networks effectively perform educational functions? Can they become a proper professional development instrument? We can formulate a lot of questions. The phenomenon of social networking websites is new and complicated, rapidly changing. However, not only the question of the use is problematic. Academic community, being inert, hardly accept any innovations. Researchers should focus not only on the students 'interest in and ability to use the Social Networking Websites, but also lecturers' attitude to the new opportunities. Therefore, exhaustive empirical researches are necessary, seeking to maximally use the SNW providing possibilities for educational purposes.

\section{References}

Lamanauskas, V. (2012a). Social Networking Websites: New Educational Space. Problems of Education in the 21st Century, 39, 5-7.

Lamanauskas, V., Šlekienė, V., Ragulienè, L. (2012b). Usage of social networking websites: Lithuanian university students' position. Problems of Education in the 21th Century, 45, 27-39.

Lamanauskas, V., Šlekienė, V., Balog, A., Pribeanu, C. (2013). Exploring the usefulness of social networking websites: a multidimensional model. Studies in Informatics and Control, 22 (2), 175-184.

Received: June 10, 20

Accepted: June 18, 2013

Vincentas Lamanauskas

PhD., Professor, Siauliai University, Natural Science Education Research Centre, 25-119 P. Vi inskio Street, LT- 76351, Siauliai, Lithuania.

E-mail: v.lamanauskas@ef.su.lt, lamanauskas@lamanauskas.puslapiai.It

Website: http://www.lamanauskas.puslapiai.lt/

Facebook: https://www.facebook.com/ScientiaEducologica 